\title{
Toward a Sustainable Model of Scientific Publishing
}

\section{Ravindra Palavalli-Nettimi}

Florida International University, Department of Biological Sciences, Miami, FL https://doi.org/10.38126/ISPG180111

Corresponding author: rvndrpn@gmail.com

Keywords: scientific societies; publishing grants; open-access; impact factor; publication; community

\begin{abstract}
Executive Summary: The current models of commercial publishing of scientific research costs universities, funding organizations, and governments billions of dollars in the form of annual subscriptions and publishing charges. Yet, many research papers are behind a paywall for the public and those unaffiliated to universities. Much of the research that is freely accessible to everyone requires authors to pay an unreasonable fee leading to inequalities in knowledge dissemination based on affordability. So, we need a sustainable model of scientific publishing that is beneficial to scientists, universities, and the public, especially in light of Covid-19 pandemic related budget cuts. Similar to commercial publishers, many scientific societies publish their own journals. Funding sources and universities should offer publishing grants or annual contributions to fund such societies' open-access journals and thus support a sustainable publishing model wherein profits generated from academic publishing are invested back into the scientific community. Funding sources should also mandate publishing papers in society journals. To encourage that, hiring committees should place more importance on the article-level metrics than journal quality metrics such as the impact factor. The societies can use the publishing grants to cover journal publication costs and pay commercial publishers only for their value-added services such as manuscript handling and hosting the content online. The proposed publishing model will be sustainable and can strengthen scientific communities by supporting scientific society journals and making science more accessible.
\end{abstract}

\section{Introduction}

How much do scientific journals pay researchers to publish their research? Nothing. On the contrary, the authors often have to pay the publishers. Scientific publishing is a multi-billion-dollar industry (Johnson, Watkinson, and Mabe 2018,22) that controls access to knowledge while benefiting from free academic labor. In this model, taxpayers have to bear the double cost of first funding the public research, then accessing the published work-a sort of 'knowledge tax' imposed by for-profit companies. In contrast to the current publishing models, I argue that supporting scientific societies and their journals can make science accessible to all. Such a model would be more sustainable as the profits generated from academic publishing can directly benefit researchers and the scientific community.

\section{i. Subscription model}

Scientists write research papers and transfer their copyright to journals while other scientists act as editors and reviewers who evaluate the research-all for free. Commercial publishers edit, type-set the research articles, print or host them online and enforce the content copyright, among other things. Though the average production cost per research paper varies a lot and is often not explicitly mentioned, the publishing companies offer journal subscription packages to university libraries ("Subscription model"). Every year, libraries spend millions of dollars on subscription fees to access various journals (Johnson, Watkinson, and Mabe 2018, 22). In 2019, Elsevier, a leading scientific publisher that owns top journals such as The Lancet and Cell, made around $\$ 1275$ million in profits on $\$ 3424$ million revenue-that is, $40 \%$ profit marginmost of it is from subscriptions in North America 
("RELX Annual Report" 2019). While the research community supplies and scrutinizes the content through peer review for free, the same content is packaged and sold back to the community at an inflated price, keeping much of the research behind a paywall.

\section{ii. Pay-to-read model}

The current Covid-19 pandemic has highlighted that we all need access to scientific knowledge. Those without institutional affiliations have to pay $\$ 10$ (for Proceedings of the National Academy of Sciences of the USA) to $\sim \$ 35$ (for Cell Press journals) to access a single research article. Even some scientists lack access to technical papers; their need is evident in the popularity of Scihub, a pirate website that makes millions of paywalled papers available to all for free. The latest peer-reviewed science, especially if funded by taxpayers, should be accessible to journalists, entrepreneurs, doctors, patients, and other people free of cost. Some funding agencies in Europe and the U.S. (e.g., National Institute of Health) have mandated that the research they paid for should be made publicly available after six or twelve months ("Elsevier Agreements" 2021). But we often need immediate access to the new peer-reviewed research. For example, Covid-19 related research should be instantly available post peer-review for free as the pandemic is an international public health emergency and the research can potentially save many lives.

\section{iii. Open-access model}

In the open-access model, the authors choose to make their findings freely accessible for all by paying Article Processing Charges (APCs) of $\$ 250$ to $\$ 6000$ per article to the journals ("Open Access Publishing Price List" 2021). From 2021, the authors have to pay close to $\$ 11400$ to make a paper open access in the journal Nature (Else 2020). The price is equivalent to a few months' stipends for graduate students in the USA. So, it is unaffordable to many scientists and directly affects diversity and inclusion in science.

As more journals are now hosting their content online, publishing costs are plummeting; but subscription fees and APCs are not, though the actual publishing cost per article can be as low as $\$ 200$ or $\$ 1000$ for journals with a $90 \%$ rejection rate (Grossmann and Brembs 2019). The open-access model with APCs is not necessarily cheaper than the subscription model and has even led to a rise in predatory open-access journals (Shen and Björk 2015, 1-15). The model shifts the burden from libraries to funding agencies and researchers. Therefore, the publishing models discussed above are unsustainable over the long term, and every stakeholder is at a disadvantage except for the commercial publishers. We need to move toward a sustainable publishing model that benefits the research community, funding agencies, and the taxpayers and truly democratize science.

\section{iv. The role of journal impact factor in academic publishing}

Journal impact factor is a metric created by the publishing industry to rank the quality of journals (Garfield 2006). It plays a role in where scientists submit their work. Knowing that journal impact factors play a vital role in the promotion, hiring, or tenure decisions of academics (McKiernan et al. 2019, 4-7), high impact factor journals charge disproportionately more to publish (Brembs 2016) and refuse to move toward a sustainable publishing model as it would reduce their profit margin. This system puts a burden on the research community as funds that could cover research expenses are used to pay commercial publishers in exchange for publishing in high impact journals.

\section{v. Scientific community-based open-access publishing: a way forward}

A sustainable publishing model is to let the scholarly community allow access to knowledge through various scientific societies. Many societies publish prestigious journals (Johnston 2017). But most of them depend on member fees and donations to run the journals. If funding sources and universities support the journals, the scientific societies can invest any profits from publishing journals back in the research community through conferences, workshops, and small research funds. Also, we need to curtail the undue importance of the journal impact factor in hiring decisions and thus discourage paying more to publish in higher impact factor journals. The societies can pay commercial publishers only for services that they provide (e.g., manuscript handling). Publishing companies should not have a monopoly in shaping taxpayer-funded science. So, we need policy changes at the institutional and funding agency levels (Table 1). 


\section{Policy recommendations}

\section{i. Fund scientific society open-access journals}

Instead of funding to pay high Article Processing Charges to the commercial journals, funding agencies should offer publishing grants to scientific society open-access journals. Similarly, university libraries or departments can pay an annual contribution to as many scientific societies as possible to cover production costs and make research articles free to access. The cost of production and maintenance of journals depends on factors such as the number of papers and services provided (e.g., copy editing, editorial software, and distribution). A representative publication cost per article is estimated to be around $\$ 400$ (Grossmann and Brembs 2019). Assuming a journal publishes 200 papers per year, the total publication cost would be $\$ 80,000$ (though it may be an under-estimate for journals that publish more issues per year). The funds currently spent by the universities and funding sources on commercial journal subscriptions and APCs can finance more journals from the societies. Funding the societies can contribute to American innovation, science advocacy, and education while also removing the barrier to knowledge dissemination (Schloss, Johnston, and Casadevall 2017). Any profit generated through publishing, donations and advertising revenue can fund small research grants to community members, creating incentives for scientists to prefer society journals.

\section{ii. Encourage publishing in scientific society journals}

Funding agencies should mandate authors to publish most of their research output in open-access scientific society journals. One of the reasons why the authors may not always submit their articles to society journals could be the journal impact factor and its central role in tenure or hiring decisions (McKiernan et al. 2019). However, a high journal impact factor does not necessarily translate to better science (Brembs 2018). Funding agencies and hiring committees should judge candidates based on the quality of their research (e.g., using article-level metrics such as citation rate (Hutchins et al. 2016; Banks and Dellavalle 2008)) rather than journal impact factors. This would help improve the quality of papers while also supporting scientific society open-access journals.

iii. Pay commercial publishers only for their valueadded services

Because scientific societies may not always have the resources to handle a large number of papers and journals, they can pay commercial publishers for services such as manuscript handling, type-setting, and content hosting services using publishing grants awarded to them. This ensures that societies can still work with commercial publishers but pay them only for the value-added services.

\section{Conclusion}

Funding society journals, instead of paying high Article Processing Charges to commercial publishers, helps keep the profits generated through academic publishing within the research community. Though commercial publishers are here to stay, scientists who contribute the research content to the journals for free can choose where to publish their work. If scientists want a sustainable solution to academic publishing problems, they need to be a part of the solution. The hard truth is that as long as hiring or tenure committees assess researchers based on journal prestige (Brembs, Button, and Munafo 2013), commercial publishing companies can maintain the monopoly and gate-keeper status by charging unreasonable fees to publish in their journals. So, the hiring committees need to assess candidates based on article-level metrics such as number of citations instead (see (Hutchins et al. 2016; Banks and Dellavalle 2008)). Funding sources should ensure that the funded research benefits the scientific enterprise and the public, and not only for-profit publishers. Ultimately, it is not just about breaking the paywalls but also bridging science to every person. Empowering scientific societies is a way toward achieving the goal. 


\section{Appendix}

\begin{tabular}{|c|c|c|c|}
\hline Problem/Challenge & Who can act & Recommendations & Benefits \\
\hline $\begin{array}{l}\text { The current publishing } \\
\text { models are unsustainable } \\
\text { to all stakeholders except } \\
\text { commercial publishers } \\
\text { Scientific societies lack } \\
\text { funding for keeping their } \\
\text { journals open-access }\end{array}$ & $\begin{array}{c}\text { Funding agencies and } \\
\text { universities }\end{array}$ & $\begin{array}{l}\text { Fund scientific society } \\
\text { journals through annual } \\
\text { contributions or } \\
\text { publishing grants }\end{array}$ & $\begin{array}{l}\text { Scientific societies get } \\
\text { funding to publish open- } \\
\text { access journals } \\
\text { Profits from such journals } \\
\text { can benefit the scientific } \\
\text { community and the public }\end{array}$ \\
\hline $\begin{array}{l}\text { Perceived journal prestige } \\
\text { as a barrier to science }\end{array}$ & Funding agencies & $\begin{array}{l}\text { Mandate to publish in } \\
\text { open-access society } \\
\text { journals }\end{array}$ & $\begin{array}{l}\text { Submissions to society } \\
\text { journals will increase }\end{array}$ \\
\hline $\begin{array}{l}\text { 'High impact' journals } \\
\text { charging unreasonably } \\
\text { high fee to publish }\end{array}$ & $\begin{array}{l}\text { Scientists and } \\
\text { administrators }\end{array}$ & $\begin{array}{c}\text { Tenure and grant } \\
\text { committees should not rely } \\
\text { on journal Impact Factors } \\
\text { in their decisions }\end{array}$ & $\begin{array}{l}\text { Researchers are evaluated } \\
\text { based on research paper } \\
\text { quality (e.g., article-level } \\
\text { metrics) rather than } \\
\text { journal Impact Factor }\end{array}$ \\
\hline $\begin{array}{l}\text { Societies often lack } \\
\text { resources to host many } \\
\text { journals }\end{array}$ & Scientific societies & $\begin{array}{c}\text { Hire services of } \\
\text { commercial publishers }\end{array}$ & $\begin{array}{l}\text { Commercial publishers } \\
\text { paid only for their value- } \\
\text { added services. }\end{array}$ \\
\hline $\begin{array}{l}\text { Most of the profits from } \\
\text { scientific publications go } \\
\text { to commercial publishers }\end{array}$ & & & $\begin{array}{l}\text { Societies can use profits } \\
\text { from their publications to } \\
\text { benefit the scientific } \\
\text { community }\end{array}$ \\
\hline
\end{tabular}

Table 1. Policy recommendations, stakeholder actions, and benefits of sustainable publishing.

\section{References}

Banks, Marcus A., and Robert Dellavalle. 2008. "Emerging Alternatives to the Impact Factor." OCLC Systems and Services $24 \quad$ (3): 167-73. https://doi.org/10.1108/10650750810898200.

Brembs, Björn. 2016. "How Gold Open Access May Make Things Worse." Björn.Brembs.Blog. 2016. Accessed Feb 10, 2021 http://bjoern.brembs.net/2016/04/how-goldopen-access-may-make-things-worse/.

Brembs, Björn. 2018. "Prestigious Science Journals Struggle to Reach Even Average Reliability." Frontiers in Human Neuroscience 12: 37. https://doi.org/10.3389/fnhum.2018.00037.
Brembs, Björn, Katherine Button, and Marcus Munafò. 2013. "Deep Impact: Unintended Consequences of Journal Rank." Frontiers in Human Neuroscience 7: 291.

$1-12$. https://doi.org/10.3389/fnhum.2013.00291.

Else, Holly. 2020. "Nature Journals Reveal Terms of OpenAccess Option" Nature News. 588: 19-20. https://doi.org/10.1038/d41586-020-03324-y

"Elsevier Agreements." 2021. Elsevier. Accessed Feb 10, 2021. https://www.elsevier.com/openaccess/agreements

Garfield, Eugene. 2006. "The History and Meaning of the Journal Impact Factor." JAMA 295 (1): 90-93. https://doi.org/10.1001/jama.295.1.90. 
Grossmann, Alexander, and Björn Brembs. 2019. "Assessing the Size of the Affordability Problem in Scholarly Publishing." Preprint. PeerJ Preprints. https://doi.org/10.7287/peerj.preprints.27809v 1.

Hutchins, B. Ian, Xin Yuan, James M. Anderson, and George M. Santangelo. 2016. "Relative Citation Ratio (RCR): A New Metric That Uses Citation Rates to Measure Influence at the Article Level." PLoS Biology $14 \quad$ (9): $1-25$. https://doi.org/10.1371/journal.pbio.1002541.

Johnson, Rob, Anthony Watkinson, and Michael Mabe. 2018. "An Overview of Scientifc and Scholarly Publishing." The STM Report. https://www.stmassoc.org/2018 1004 STM Report 2018.pdf.

Johnston, Mark. 2017. "Scientific Society Journals: By Scientists for Science." Genetics 207 (4): 12291230

https://doi.org/10.1534/genetics.117.300427.

McKiernan, Erin C., Lesley A. Schimanski, Carol Muñoz Nieves, Lisa Matthias, Meredith T. Niles, and Juan P. Alperin. 2019. "Use of the Journal Impact Factor in Academic Review, Promotion, and Tenure Evaluations." $\quad$ ELife 8: 1-12. https://doi.org/10.7554/eLife.47338.
“Open Access Publishing Price List.” 2021. Elsevier. Accessed Feb 10, 2021 https://www.elsevier.com/books-andjournals/journal-pricing/print-price-list.

"RELX Annual Report." 2019. Accessed Feb 10, 2021. https://www.relx.com/ /media/Files/R/RELXGroup/documents/reports/annualreports/2019-annual-report.pdf.

Schloss, Patrick D., Mark Johnston, and Arturo Casadevall. 2017. "Support Science by Publishing in Scientific Society Journals." MBio 8 (5): e01633-17. https://doi.org/10.1128/mBio.01633-17.

Shen, Cenyu, and Bo-Christer Björk. 2015. "Predatory' Open Access: A Longitudinal Study of Article Volumes and Market Characteristics." BMC Medicine $13 \quad$ (1): 230. https://doi.org/10.1186/s12916-015-0469-2.

Ravindra Palavalli-Nettimi is a post-doctoral research associate at Florida International University. Ravindra received his Ph.D. from Macquarie University, Sydney, Australia. He studies insect vision, flight, and navigation.

\section{Acknowledgements}

I am grateful to all the instructors and organizers of the Science Policy and Advocacy Certificate Program for STEM Scientists (UC-Irvine/JSPG). Thanks to Max Schneider and Ankita Arora for their feedback on earlier drafts of the article. 